\title{
THE EFFECT OF ROLE PLAY TECHNIQUE AND PERSONALITY TYPES ON THE SPEAKING COMPETENCY OF THE ELEVENTH GRADE STUDENTS OF S WIRA HARAPAN TEGALJAYA
}

\author{
Retny, A. \\ Language Education Study Program, Postgraduate Program \\ Ganesha University of Education \\ Singaraja, Indonesia \\ e-mail:retny.asriyani@pasca.undiksha.ac.id \\ Jayaputra, I.N. A, \\ Language Education Study Program, Postgraduate Program \\ Ganesha University of Education \\ Singaraja, Indonesia \\ Ratminingsih, N.M. \\ Language Education Study Program, Postgraduate Program \\ Ganesha University of Education \\ Singaraja, Indonesia
}

\begin{abstract}
This research aimed at investigating the effect of role play technique and personality types on the speaking competency. Particulary, this research aimed at investigating whether or not between students who are taught by using role play and those who are taught by conventional technique there is (a) a significant difference in speaking competency; (b) a significant difference of speaking competency between extrovert students and introvert students; (c) an interactional effect of the implementation of teaching techniques and students' personality types in speaking competency ; (d) a significant difference in speaking competency between extrovert students and (e) a significant difference in speaking competency between introvert students. This study was conducted at the eleventh grade students of SMK Wira Harapan Tegaljaya. To answer the research problems, $2 \times 2$ factorial designs was implemented. The collected data were analyzed descriptively and inferentially by using IBM SPSS Statistics. From the result of the study, it can be concluded that: (1) There is a significant difference of speaking competency between students who are taught by using role play technique and who are taught by using conventional technique, (2) there is a significant difference of speaking competency between extrovert students and introvert students, (3) there is no interaction effect between students personality and role play technique on students speaking competency. (4) there is a significant difference of speaking competency between extrovert students who are taught by using role play technique and those who are taught by using conventional technique and (5) there is a significant difference in speaking competency between introvert students who are taught by using role play technique and those who are taught by using conventional technique. These findings are expected to have important contribution to EFL speaking classroom in Indonesia especially for eleventh grade students in SMK Wira Harapan Tegaljaya.
\end{abstract}

Keywords: Role Play, Personality Types, Speaking Competency

\section{INTRODUCTION}

The major goal of teaching in Indonesia is to enable the students to develop their communicative competency in four language skills, namely listening, speaking, reading and writing skill. Among those skills, speaking in a second or foreign language has often been viewed as the most demanding of the four skills (Bailey and Savage, 1994). Richard (2008) states that a large percentage of the world's language learners study English in order to develop proficiency in speaking. Adding that point, Alexander (1993) 
states that students' knowledge of English will be judged by the world at large not on his capacity to write the language but to speak it. It is the productive skill that can be directly and empirically observed (Brown, 2000). Same as the other skills, speaking skill also takes a part as the important point in determining whether or not a person is considered successful in acquiring the language. From these quotations it is assumed that speaking or oral ability is the most important skill that students need to master as foreign language learners.

However, mastering speaking competency in speaking itself is hard. Nunan (1987) states that speaking skill involves the ability of pronouncing the distinctive sounds of a language clearly, using stress, rhythmic patterns, and intonation patterns of the language in a good way, using the correct forms of words, putting words together in correct word order, using vocabularies appropriately, using the register or language variety that is appropriate to the situation and the relationship to the conversation partner, making the listener become clear to the main sentence constituents, making the main ideas stand out from supporting ideas or information, and making the discourse hang together so that people can follow what the speaker said. This theory implies that speaking is more complicated that was is thought.

Besides that, in order to teach the students well, teachers in vocational school need to get to know the students as well as possible. There are different behaviors of students in receiving and responding language learning. They have different types of personality. Personality is defined as "the organized, developing system within the individual that represents the Collective action of that individual's major psychological subsystems" (Mayer, 2007, p. 14). Each individual has specific personality to behave as a respond to a different way in learning. Personality can affect students' behavior in the classroom and academic success, contributing to the relationships students have with their teachers and peers (Matthews, Zeidner, \& Roberts, 2007). It is also important for teachers to have an awareness of students' personality.

Based on the reason above, the researcher wants to overcome the students' problem of discouragement in speaking by using Role-Play technique. In relation to it, Larsen-Freeman (1986) explains that role plays, whether structured or less structured, are important in the communicative approach because they give learners an opportunity to practice communicating in different social contexts and roles.

Based on the quotation above, the researcher assumes that Role-Play can be used as the technique of teaching and learning process and helps students to interact in any situation. Role-Play helps the students with different personality and liberates the students with difficulty in conversation. Furthermore, role play offers most students with some enjoyment which leads to better learning process. Another reason is to train the students about how to practice English by giving a chance to express their ideas, opinions, and thoughts. In addition, the researcher wants to find out whether Role-Play is an appropriate technique for teaching student's speaking competency with different type of personality.

Therefore this thesis focused on investigating whether or not between students who are taught by using role play and those who are taught by conventional technique there is (a) a significant difference in speaking competency; (b) a significant difference of speaking competency between extrovert students and introvert students; (c) an interactional effect of the implementation of teaching techniques and students' personality types in speaking competency ; (d) a significant difference in speaking competency between extrovert students and (e) a significant difference in speaking competency between introvert students.

\section{METHODS}

The research design adopted in this study was Post-test only control group design. Fraenkel and Wallen (1993: 248) stated that Post-test only control group design involves two groups in which one of them receives experimental treatment, while another does not. In the end, both groups are given post-test.

The population of this study is 469 eleventh grade students of SMK Wira Harapan Tegaljaya which were separated into 13 classes. At first, these 13 classes were tested its normality. From this process, only 4 classes from 13 classes who fullfil this criteria. Those four classes are XI AP 1, XI JB 1, XI JB 4 and XI UPW. After that, two classes were chosen from the rest 4 classes by using lottery technique. After the lottery, class XI AP 1 and XI JB 1 were chosen as sample. These 2 classes then were given a homogeneity test. The result of this study showed that the classes that became the sample of this study were already 
homogeneous. The classes who were already proven to be normal and homogeneous became the samples of this study. These classes then were given a personallity questionnaire to find out who out of the students can be categorized as extroverts and introverts.

After being tested, students were given treatments. The experimental group was given role play technique and control group was treated by using conventional technique in form of chain drill. The treatment lasted for 8 meetings. In the end of the treatments the two classes were given speaking competency test.

After that, the data would be described and analyzed inferentially. Inferential analysis was done to test the research hypotheses and to answer the research questions of this study. Based on the research designs, hypotheses testing would be administered. Based on the research designs, the analysis was administered by using Two-way ANOVA and followed by Tukey test to know the interaction effect.

\section{FINDINGS AND DISCUSSION}

The aim of this study was to investigate the significant difference of Role Play technique on student's speaking competency between the students who were treated by role play technique and the students who were treated by conventional technique taking into consideration students' personality in form of extroversion and introversion. The data obtained were categorized into 8 groups, namely:

a. Group AI covers the group of the students who were treated by using role play technique

b. Group A2 covers the group of the students who were treated by using conventional technique

c. Group B1 covers group of students with extrovert personality types

d. Group B2 covers group of students with introvert personality

e. Group A1B1 covers the group of students being treated by using role play technique and having extrovert personality types.

f. Group A1B2 covers the group of the students being treated by using role play technique and having introvert personality types

g. Group A2B1 covers the group of the students being treated by using conventional technique and having extrovert personality types

h. Group A2B2 covers the group of the students being treated by using conventional technique and having introvert personality types.

These groups were analyzed both descriptively and inferentially. Below, the descriptive and inferential analysis was presented.

Table 1 Descriptive Statistics of Students' Speaking Competency

\begin{tabular}{|c|c|c|c|c|}
\hline & $\mathbf{N}$ & Mean & Std. Deviation & Variance \\
\hline A1 & 30 & 14.87 & 2.29 & 5.22 \\
\hline A2 & 30 & 12.30 & 2.64 & 6.98 \\
\hline B1 & 30 & 15.47 & 2.11 & 4.46 \\
\hline B2 & 30 & 11.70 & 1.95 & 3.80 \\
\hline A1B1 & 15 & 16.67 & 1.68 & 2.81 \\
\hline A2B1 & 15 & 14.27 & 1.83 & 3.35 \\
\hline A1B2 & 15 & 13.07 & 1.03 & 1.07 \\
\hline A2B2 & 15 & 10.33 & 1.68 & 2.81 \\
\hline
\end{tabular}

From the table above, students speaking competency was better when students were treated by using role play and especially when they were already extrovert to begin with 
First of all, when students in experimental group who were treated by using role-play were compared with students who were treated conventionally, students in experimental group showed better result. The mean score of students speaking competency in experimental group was 14.87 . It was better by 2.57 points that students' speaking competency in control group whose score was 12.30 .

Second, when extrovert students were compared with introvert students, it can be seen that extrovert students has better speaking competency than control group. From the mean score, the extrovert students mean scores were 15.47. On the other hand, introvert students' mean scores were 11.7. It means that extrovert students had better score by 3.77 points.

Third, if the extrovert students with different treatment were compared, it was observed that experimental group showed better result than control group. For extrovert students who were treated by using role play, the mean score was 16.67 . On the other hand, the group who was treated conventionally showed that their mean score was 14.27. It means that for extrovert students, role play had given better scores by 2.4 point than conventional technique

Finally, if introvert students were compared, it still can be seen that experimental group had better scores by 2.74 points. The experimental group mean score was 13.07 , while control group mean score was 10.33 .

From the explanation above, it could be seen that experimental group was generally better than control group. Additionally, the data above implies that the role play technique worked better for both extrovert students and introvert students. Therefore, the implementation of role play technique can be said is better for students' speaking competency than chain drill technique. However, to decide whether these differences are significant or not, an inferential analysis in form of two way anova was used.

Two way anova cannot be conducted without fulfilling two pre-requisite tests namely normality test and homogeneity test. Therefore a normality test and homogeneitey test were conducted.

For the normality test, below the result of the test is shown.

\section{Table 2 Normality Test of Data}

\section{Tests of Normality}

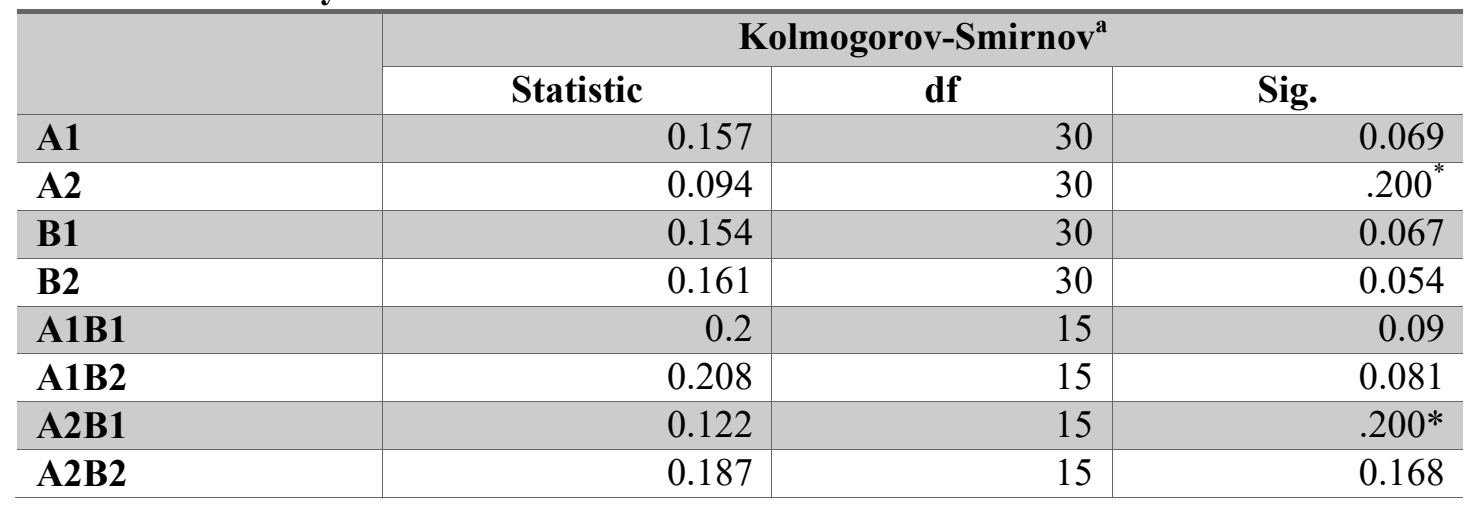

From the data above it could be seen that the significant values of each group varied. The significant value for group A1 is 0.069 , for group A2 is 0.200 , for group B1 is 0.067 , for group B2 is 0.054 , for group A1B1 is 0.090 , for group A1B2 is 0.081 , for group A2B1 is 0.122 and for group A2B2 is 0.168 . The data could be called as normal when the data's significant values are more than 0.05 All the numbers which were presented above are more than 0.05 . Therefore, it can be concluded that all the data are normally distributed.

The second pre-requisite tests that need to be fulfilled is test of homogeneity of variance. The homogeneity of variance test was administered to find out whether or not the samples under study were homogenous. Homogeneity of variance in this study was administered by Levene test and the result of the testing can be presented in the table below 
Table 3. The Result of Homogeneity Test of Speaking Competency Scores

\begin{tabular}{|cl|r|}
\hline & \multicolumn{1}{|c|}{ Sig. } \\
\hline \multirow{3}{*}{ Scores } & Based on Mean & .297 \\
& Based on Median & .326 \\
& Based on Median and & .326 \\
& with adjusted df & .305 \\
\hline
\end{tabular}

From the table above, it can be seen that the significant value based on mean was 0.297 , based on median was 0.326., based on median and with adjusted df was 0.326 and based on trimmed mean was 0.306 . The data can be said as homogeneous when the significant values of each element are above 0.05. Since all significant values were above 0.05 , the data could be said as homogeneous.

The two tests that had been conducted above proved that the data were normal and homogeneous. Therefore, the data could be processed to the next test which was hypothesis testing.

The first aim of this research is to investigate whether or not there is a significant difference of speaking competency between students who are taught by using role play technique and who are taught by using conventional technique. The hypothesis that is formulated for this research is "There is a significant difference of speaking competency between students who are taught by using role play technique and who are taught by using conventional technique."

Previously, it has been explained that experimental group who were treated by using Role play had better average speaking competency score by 2.57 points than students who were treated conventionally. It means that students in experimental group performed better than students in control group. However, whether or not this difference is significant, it needs further analysis.

To test this hypothesis, two-way anova was used. The result of this hypothesis testing can be seen below

Table 4 Hypothesis Testing for First Research Aim

\begin{tabular}{|l|r|r|}
\hline \multicolumn{1}{|c|}{ Source } & \multicolumn{1}{c|}{ F } & \multicolumn{1}{c|}{ Sig. } \\
\hline Corrected Model & 41.449 & .000 \\
\hline Intercept & 4411.361 & .000 \\
\hline Technique & 39.377 & $\mathbf{. 0 0 0}$ \\
\hline
\end{tabular}

From the table 4 , it can be seen that the significant value is 0.00 . The difference could be called significant when the significant value is below 0.05 . Since 0.00 is below 0.05 , it can be concluded that students in experimental group had significantly better score than students in the control group. The hypothesis was accepted. The conclusion for this finding is "There is a significant difference of speaking competency between students who are taught by using role play technique and who are taught by using conventional technique."

Second research aim concerns on investigating whether or not there is a significant difference of speaking competency between extrovert students and introvert students. For this, the hypothesis that is 
formulated is there is a significant difference of speaking competency between extrovert students and introvert students.

The mean score between these two groups has been explained above. In this experiment, extrovert students had better score by 3.77 points which means that extrovert students performed better than introvert students. However, to prove that the difference of speaking competency scores between extroverts and introverts, further analysis is needed. For this purpose, two way anova was used and the result can be seen below.

Table 5.Result of Hypothesis Testing for Second Research Aim

\begin{tabular}{|l|r|r|}
\hline \multicolumn{1}{|c|}{ Source } & \multicolumn{1}{c|}{ F } & \multicolumn{1}{c|}{ Sig. } \\
\hline Corrected Model & 41.449 & .000 \\
\hline Intercept & 4411.361 & .000 \\
\hline Personality & 84.804 & $\mathbf{. 0 0 0}$ \\
\hline
\end{tabular}

From the table above, it can be seen that the sig. score was 0.000 . It has been explained previously that this difference would be called significant when the sig value is below 0.05 . Since 0.000 is below 0.05 , it can be said that there is significant difference of speaking competency between extrovert students and introvert students. Therefore, it can be concluded that "there is a significant difference of speaking competency between extrovert students and introvert students."

The third hypothesis testing focuses on investigating whether or not there is an interactional effect of the implementation of teaching techniques and students' personality types in speaking competency. For this, a hypothesis has been formulated which is there is an interactional effect of the implementation of teaching techniques and students' personality types in speaking competency.

To find out the answer of this research question, Two-Way ANOVA Test by using IBM SPSS was used. The result can be seen in the table below

Table 6. Result of Hypothesis Testing for Second Research Aim

\begin{tabular}{|l|c|}
\hline \multicolumn{1}{|c|}{ Source } & Sig. \\
\hline Technique * Personality & .685 \\
\hline Error & \\
\hline Total & \\
\hline Corrected Total & \\
\hline
\end{tabular}

From the table above, it can be seen that the sig score was 0.685 . The interactional effect happened when the sig value is below 0.05 . Since 0.685 is higher than 0.05 , it can be concluded that there is no interaction effect between students personality and role play technique on students speaking competency. To justify this finding further, a diagram of interaction effect is showed below 


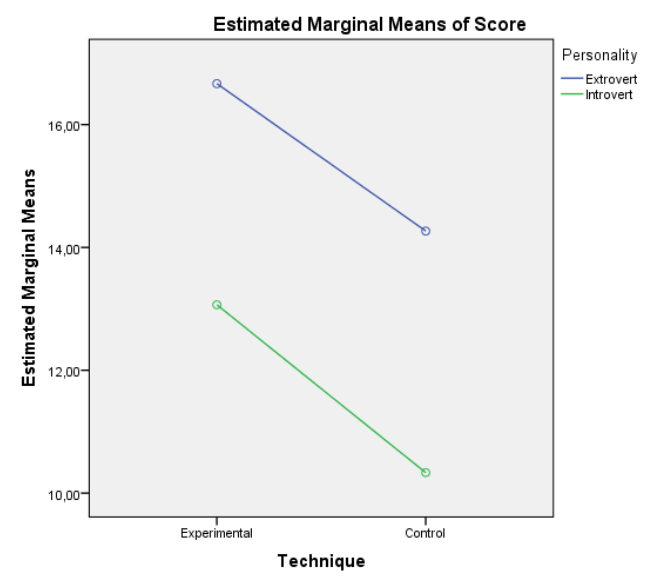

Figure 1. Interaction between Role Play Technique and Students Personality

From the picture above, it can be seen that there is no interaction between those two lines. The lines stand separately which prove the absence of interaction effect between these two variables. The hypothesis for this research aim is rejected. Finally, it could be concluded that "there is no interaction effect between students personality and role play technique on students speaking competency."

The fourth hypothesis testing focuses on investigating whether or not there is a significant difference of speaking competency between extrovert students who are taught by using role play technique and those who are taught by using conventional technique. The hypothesis formulated is there is a significant difference of speaking competency between extrovert students who are taught by using role play technique and those who are taught by using conventional technique.

The descriptive statistics of this data has clearly shown that experimental group showed better result than control group. For extrovert students who were treated by using role play, the mean score was 16.67. On the other hand, the group who was treated conventionally showed that their mean score was 14.27 . It means that for extrovert students, role play had given better scores by 2.4 point than conventional technique.

To prove that the effect of role play is significantly better than conventional technique, a tukey test was applied. The result of tukey test can be seen below.

Table 7. Result of Tukey Test of Extrovert Students' Speaking Competency

\begin{tabular}{|c|c|c|c|c|}
\hline Strategy & Role Play & $\begin{array}{c}\text { Conventional } \\
\text { Technique }\end{array}$ & Q & Q table \\
\hline Mean & 16.67 & 14.27 & 7.24 & 2.84 \\
\hline Degree of Freedom & \multicolumn{2}{|c|}{28} & & \\
\hline
\end{tabular}

The difference can be called significant when the $\mathrm{Q}$ value is more than $\mathrm{Q}$ table. From the table above, it can be seen that the $\mathrm{Q}$ value is 7.24. The $\mathrm{Q}$ table when the degree of freedom is 28 is 2.84 . It could be seen that $q$ values is more than $\mathrm{q}$ table. Therefore, it could be said that there is a significant difference of speaking competency between extrovert students who are taught by using role play technique and those who are taught by using conventional technique.

Finally, the fifth hypothesis testing aimed at investigating whether or not there is a significant difference in speaking competency between introvert students who are taught by using role play technique and those who are taught by using conventional technique. For this, the hypothesis proposed is there is a significant difference in speaking competency between introvert students who are taught by using role play technique and those who are taught by using conventional technique. 
From the descriptive statistics, it is found that introvert students were better when they were treated by using role play technique. The experimental group mean score was 13.07 , while control group mean score was 10.33. It means that experimental group had better score by 2.74 points.

To prove whether this difference is significant, tukey test was used. The result of tukey test can be seen below.

Table 8. Result of Tukey Test of Introvert Students' Speaking Competency

\begin{tabular}{|c|c|c|c|c|}
\hline Strategy & Role Play & $\begin{array}{c}\text { Conventional } \\
\text { Technique }\end{array}$ & Q & Q table \\
\hline Mean & 13.07 & 10.33 & 10.39 & 2.84 \\
\hline Degree of Freedom (Df) & \multicolumn{2}{|c|}{28} & & \\
\hline
\end{tabular}

From the data above, it could be seen that the q value was 10.39 and the $q$ table is 2.84 . Since the $q$ value is more than the $\mathrm{q}$ table, the hypothesis is accepted and it can be concluded that there is a significant difference in speaking competency between introvert students who are taught by using role play technique and those who are taught by using conventional technique

Regarding the finding that students in experimental group did significantly better than students in control group, the sign of these differences can be seen during the classroom process.

The first sign that appears is students in experimental group were more interested in the learning material than students in control group. At the first time, however, some students hesitated to participate in the learning process. Only several students that were excited to do the role play. But, with some words of motivation, students start to open to this technique. The number of students who participate in the classroom increased in every meeting. The reason of this phenomenon is the fun aspect that is offered by role play. First, students work in the group where they actively participated to create a good performance in front of the classroom. While they were discussing each other, they can dream and imagine further to create a good conversation. In addition, working with friends make the learning process more enjoyable. It was because they can freely and comfortably ask the material that students does not understand. While learning alone, some students kept their question inside because they felt fear when they have to ask something to the teacher. But with their groups they can express theirselves better. While they are performing, the other students watched the performance as entertainment. They laughed together when the role play is funny and even when the performers did some mistakes in the performance. Different from the control group, the chain drill technique made some students feel uneasy. Instead of being interested in the classroom material, some students feel scared. Not all students could answer the question regarding material that was taught. Especially, because they needed to answer the question by themselves, some students who cannot understand the material feel scared that they would be asked to answer the questions. Additionally, some students had issues in their confidence which made them did not speak at all in the classroom. This phenomenon is actually had been stated by Ladousse (1987) who stated that role plays introduce a lot of fun into the classroom. Role play provides favorable atmosphere which allows the students to express themselves as fluently and freely as possible without hesitation

Second phenomenon that was observed is students in experimental group became more active. From the very beginning the theme of the role play was announced, the students became busy with their performance. They actively designing from writing the script that they would do, choosing the costume that they wore in the performance until preparing the properties needed to complete their performance. Everyone engaged in this learning process. Moreover, since the role play would be performed in front of the classroom, students becomes busy practicing. The students who do not understand how to pronounce some words, ask to the other smarter students on the pronunciation. The students who could not act well were corrected by their friend. The students worked hard together since the scores that they got were based on the performance that they did. If there were some group mates who did not practiced seriously, it could harm other students. Therefore, almost all students tried hard to make a good performance. On the other hand, students in control group who were taught by using chain drill usually only wait for the teacher to answer the question. The material were all taught by the teacher. The only assignment that they 
needed to do is to answer the questions regarding the material. While it is not necessarily bad, but the students were put as passive learner. Most of the time they become a passive person who only heard the teacher's explanation. They only spoke when the teacher asked and be silent if no one asked them. With this different phenomenon between the two groups, it was obvious that experimental group did better. Furthermore, these phenomenon matches with the theory from Ladousse (1987) who stated that while doing role play, all learners have an opportunity to be active.

Third reason that has been able to be identified is applying role play can train students to be able to use English in different situation. While teaching with role play, different situation were assigned to students. These situation were chosen based on the real life situation that might be faced by students later on. Therefore, the situation itself is already authentic enough for students to learn. Students learn this contextual material in three way. First, students learn to write the script based on the contextual situation. The students have to deal with this assignment and make the conversation based on what they had been told to. Second, students can practice to speak the theme that they are assigned to. Finally, students can listen to the use of English in different situation by hearing all the other performances. Learning different conversation from different contextual situation is essential for students' English speaking development. Through this, students were able to deal with different conversation that they may face in the speaking competency test and also real life. Role-play technique is appropriate for the teaching because a wide variety of experience can be brought in the class room through role play. It puts students in situation in which they are requiring to use and improve aphetic forms of language, and a very useful dress rehearsal for real life. It enables them not just to acquire set phases, but to learn how interaction might take place in a variety of situation. This was different from the phenomenon that happened in the control group which were treated by chain drill technique. Students mostly learned from the book and their teacher. However, it should be noted that books sometimes were not relatable for some student. Since students were only just drilled with several text and answer questions session, students' conversation mostly revolved from the book. Students does not have any chance to develop their own conversation and just answering the question based on what they read in the book. However, the text might not have any correlation at all with the students which make the students might not fully understand the material. These phenomenon make the students knowledge on how to use English are limited only on what is in the book not on how to use English in contextual way. Based on this situation, it is obvious that students in experimental group were able to use English better because they were more prepared to deal with different situation. This finding is actually in line with the theory that is stated by Brown (2000) about appropriate technique to teach speaking. Technique for teaching speaking should encourage the use of authentic language in meaningful context. Authenticity of language used and the correct meaningful real-life context would help students to practice on how and what they could do while facing problem later.

For extrovert students, it was found that students who were taught by using role-play technique had significant better effect than students who were treated by chain drill technique. The role play technique is obviously the better technique for students with this kind of personality. There are several phenomenon why role play technique match extroverts significantly better than chain drill technique.

The first phenomenon observed is the involvement of extroverts of different activities that are offered by role play technique. There are many activities that can be done by students if the teacher applied role play technique such as writing a script, designing the performance etc. While creating a script for the role play, the extroverts actively gave their own ideas to the performance. They gave ideas on how the script should be and how the storyline would develop. Sometimes, they also asks what the other group mates think about the scripts which make the other students, both extroverts and introverts, gave their own ideas too. Additionally, they also actively help the performance to be better. It was already known that the extroverts were outgoing. Not only about giving ideas, they were also willing to help making the properties or finding the equipment needed for the role play. It was different from what happen in control group who were taught by chain drill technique. The extrovert group seemed cannot do anything. They might want to participate more, but the chance for them to participate was limited. They needed to share something but the questions sometimes were already directed to other students. The limited activities of chain drill technique make these extrovert students cannot give their own creative ideas. Therefore the 
extroverts in the control group either feel two things. There were might be a lot of disappointment when they cannot participate in the classroom or they just stay silent because they feel like their effort to be shown is pointless because the limited time of participation in the classroom. For that reason, extroverts students match better with role play technique. This phenomenon was in line with some theories. Extroverts get energy from active involvement in events and having a lot of different activities. According to Martin (1997), extroverts are excited when they are around people and like to energize other people. They like moving into action and making things happen. They generally feel at home in the world. They often understand a problem better when they can talk out loud about it and hear what others have to say. (Martin , 1997). Extroverts tend to think and talk at the same time, and formulate their ideas best by saying them out loud (Laney, 2001). Furthermore, Oliver (2012) states that there are several characteristics of extroverts. They are tough-minded, impulsive, and outgoing. Additionally, whenever there is some excitement in their learning process, their learning performance will be enhanced.

Meanwhile for introverts it was also found that there is a significant difference in speaking competency between introvert students who are taught by using role play technique and those who are taught by using conventional technique in favor of those who were taught by using role play technique. For introverts after several observation it was found out that it is better to force these students to speak rather than let them staying silent in the classroom. However, considering the introvert personality which is shy, the warm environment that welcome them is needed.

There were several reasons why introvert students who were taught by using role play technique can develop significantly better than students who were taught by using chain drill technique. First of all, role play technique is a a group work (Ladousse, 1987) where students can share their ideas for better performance. This group work actually could give positive contribution to introvert students' performance. First of all, these introvert students were more open to their peers rather than to their teacher. In the normal teaching learning process, introvert students tend to be silent and not show themselves at all. Introvert students sometimes were hesitant to speak because of their personality. The problem is in this situation. In the control group classroom, introvert students somehow do not want to ask anything even if they cannot understand the material being taught. Therefore, the teacher or other students cannot help them at all to overcome their difficulties. Teacher and other students only have limited time to locate the students difficulties. The only chance for teacher to see the students' problem is when the students were asked to answer the problem given. Even with that, because the answer of the problem mostly was in the book, students difficulties in learning were hardly found. Thus it is even harder to help to get their problem fixed. However, in the experimental group classroom, even if the teacher cannot locate the students' difficulties, since these introvert students were with their friends with the same age, introvert students appeared to be more open. These introvert students had been with their friends for 2 years. Therefore it was more comfortable for students to ask anything to their friends rather than to teacher. They could freely ask anything that they still did not understand to their friends. As an effect, they could understand more about what they need to do in the classroom. This was in line with theory that had been proposed by Ladousse (1987) who stated that, role play technique provides favorable atmosphere which allows the students to express themselves as fluently and freely as possible without hesitation

The second reasons are introverted students had time to process the conversation that happen in more than one situation. While applying role play technique, students did not only perform but also heard and watched what the other teams had prepared for their performance. There are various performance presented with different theme for each performance. Therefore, these students had more references about the conversation that may appear in different occasion. Not only they were able to hear it, they could also find out different kind of expression, vocabularies or phrase that can be used in different occasion. Obviously, it enriched students knowledge about speaking itself. It was different from control group. While the teaching learning process occurred introvert students in the control group had good performance. They could answer the questions that were given to them. However, all they had to do is reading and answering based on what they read. Therefore the topics that they understood were limited. The lack of references in the control group made them were not prepared enough when they had to face 
the speaking competency tests. They were clueless on what they should speak since their experience of speaking were limited. What happened in the classroom were actually in line with what had been stated by Ladousse (1987) who stated that role play uses different communicative techniques and topics and develops fluency in the language and promotes interaction.

All of these finding had proven that Role play as a technique is significantly effective to improve students speaking competency. This finding has added some contribution on the list of good effect of role play technique on different type of learning. In other words, this thesis has supported some previous research by Vizeshpar, et .al. (2013), Yousefzadeh (2013), Rahimy (2012), Mogra (2012) and Kerr, et.al. (2013) which had been mentioned in the empirical review before. Role play technique had given significant better effect to speaking competency if all students in SMK Wira Harapan Tegaljaya.

\section{CONLUSIONS AND SUGGESTIONS}

After doing the experiment, it can be concluded that (1) There is a significant difference of speaking competency between students who are taught by using role play technique and who are taught by using conventional technique, (2) there is a significant difference of speaking competency between extrovert students and introvert students, (3) there is no interaction effect between students personality and role play technique on students speaking competency. (4) there is a significant difference of speaking competency between extrovert students who are taught by using role play technique and those who are taught by using conventional technique and (5) there is a significant difference in speaking competency between introvert students who are taught by using role play technique and those who are taught by using conventional technique.

From the result of the study above, it is recommended for teacher in SMK Wira Harapan to implement the Role Play Technique while teaching speaking. It is already proven that implementation of role play technique had given remarkably better effect on students performance in speaking. This technique is not only effective for certain students, but it gives significant better impact for both extroverts and introvert students. Therefore, the implementation of role play for teaching speaking competency is highly encouraged. However, There might be several problems occurred while implementing this technique. Some students might not accept this technique in the beginning. Therefore a good preparation and planning of role play is essential for the active participation of students. It is highly encouraged to find the topic that is really close with students' life. It is also encouraged to provide a warm environment for students so they can express and speak comfortably during the classroom.

Finally, this thesis is still far from perfection. Therefore, considering the research was done in limited population and sample, it will be empirically important for other researchers who would conduct further research could expand the experiment on the bigger population or sample. In addition, the variables of the research can also be expanded to see whether role play technique can give same impact on different type of personalities or other affective factors.

\section{REFERENCES}

Alexander, L.G 1993 Question and answer: graded oral comprehension exercise. Yogyakarta: PenerbitKanisius, Longman Grow Limited.

Bailey, K., \& Savage, L. 1994.New ways in teaching speaking. Alexandria,VA: Teachers of English to Speakers of Other Language TESOL.

Brown, D. H. 2000. Principles of language learning \& teaching. 4th ed.. New York: Longman.

Fraenkel, J.R and Wallen, N.E. 1993.How to design and evaluate research education. Singapore: Mc.GrawHill.inc. 
Kerr, D., Troth, A., Pickering, A. 2013. The Use of Role-Playing To Help Students Understand Information Systems Case Studies. Journal of Information Systems Education, Vol. 14. Retrieved

Ladousse, G. P. 1987. Role play. Oxford: Oxford University Press.

Laney, M. O. 2001. The introvert advantage: How to thrive in an extrovert world. New York: Workman Publishing.

Larsen-Freeman, D 1986 Techniques \& Principles in language Teaching. Oxford: Oxford University Press.

Martin, C.R. 1997. Extraversion or introversion. Retrieved from http://www.myersbriggs.org/my-mbtipersonality-type/mbti-basics/extraversion-or-introversion.htm. on 3 January 2013.

Matthews, G., Zeidner, M., \& Roberts, R. D. 2007. Emotional intelligence:Knowns

Mayer JD. 2007. Emotion, intelligence, emotional intelligence. in the handbook of affect and social cognition. New Jersey: Erlbaum

Mogra, I. 2012. Role play in teacher education: is there still a place for it. teacher education advancement network journal. from http://194.81.189.19/ojs/index.php/TEAN/article/viewFile/127/243 on 13 May 2013

Nunan. D. 1987. Communicative language teaching: Making it work. English Language Teaching Journal, 41, 136-145.

Oliver, K.A. 2012. Introversion/extraversion : Dimension of Personality.Retrieved from https://lib.ku.edu/sites/lib.drupal.ku.edu/files/docs/KULSS/INTROVERSIONEXTRAVERSION. pdf. on 24 December 2012

Rahimy, R., Safarpour, S. 2012. The effect of using role-play on iranian efl learners' speaking ability. Asian Journal Of Social Sciences \& Humanities. Retrieved from http://www.ajssh.leenaluna.co.jp/AJSSHPDFs/Vol.13/AJSSH20121.3-06.pdf on 13 May 2013

Richard, J.C. 2008. Teaching listening and speaking: from theory to practice. Cambridge: Cambridge Press University.

Vizeshfar, F., Dehghanrad, F., Magharei, M., Sobhani, J. 2013. Effects of applying role playing approach on nursing students' education. international journal of humanities and cultural studies. Retrieved from https://www.researchgate.net/publication/307378846_Effects_of_Applying_Role_Playing_Appro ach_on_Nursing_Students\%27_Education on 15 May 2013

Yousefzadeh, M., Hoshmandi, M.S. 2013. A study of educational effect of applying role -playing teaching method in history classroom. International Research Journal of Applied and Basic Sciences. Retrieved from http://www.irjabs.com/files_site/paperlist/r_2109_140331151247.pdf on 13 May 2013 